\title{
PSA Level Less than One
}

National Cancer Institute

\section{Source}

National Cancer Institute. PSA Level Less than One. NCI Thesaurus. Code C153421.

A blood concentration of prostate specific antigen less than $1 \mathrm{ng} / \mathrm{mL}$. 